\title{
Organic sediment formed during inundation of a degraded fen grassland emits large fluxes of $\mathrm{CH}_{4}$ and $\mathrm{CO}_{2}$
}

\author{
M. Hahn-Schöfl ${ }^{1}$, D. Zak ${ }^{2}$, M. Minke ${ }^{3}$, J. Gelbrecht ${ }^{2}$, J. Augustin ${ }^{4}$, and A. Freibauer ${ }^{5}$ \\ ${ }^{1}$ Max Planck Institute for Biogeochemistry, Hans-Knöll-Strasse 10, 07745 Jena, Germany \\ ${ }^{2}$ Leibniz Institute for Freshwater Ecology and Inland Fisheries e. V. (IGB), Müggelseedamm 301, 12561 Berlin, Germany \\ ${ }^{3}$ APB BirdLife Belarus, Surganova 2v, Minsk, Belarus \\ ${ }^{4}$ Leibniz Centre for Agricultural Landscape Research e. V., Eberswalder Strasse 84, 15374 Müncheberg, Germany \\ ${ }^{5}$ Johann Heinrich von Thünen Institute, Federal Research Institute for Rural Areas, Forestry and Fisheries, Bundesallee 50, \\ 38116 Braunschweig, Germany
}

Received: 15 September 2010 - Published in Biogeosciences Discuss.: 22 December 2010

Revised: 3 May 2011 - Accepted: 16 May 2011 - Published: 16 June 2011

\begin{abstract}
Peatland restoration by inundation of drained areas can alter local greenhouse gas emissions as $\mathrm{CO}_{2}$ and $\mathrm{CH}_{4}$. Factors that can influence these emissions include the quality and amount of substrates available for anaerobic degradation processes and the sources and availability of electron acceptors. In order to learn about possible sources of high $\mathrm{CO}_{2}$ and $\mathrm{CH}_{4}$ emissions from a rewetted degraded fen grassland, we performed incubation experiments that tested the effects of fresh plant litter in the flooded peats on pore water chemistry and $\mathrm{CO}_{2}$ and $\mathrm{CH}_{4}$ production and emission.

The position in the soil profile of the pre-existing drained peat substrate affected initial rates of anaerobic $\mathrm{CO}_{2}$ production subsequent to flooding, with the uppermost peat layer producing the greatest specific rates of $\mathrm{CO}_{2}$ evolution. $\mathrm{CH}_{4}$ production rates depended on the availability of electron acceptors and was significant only when sulfate concentrations were reduced in the pore waters. Very high specific rates of both $\mathrm{CO}_{2}$ (maximum of $412 \mathrm{mg} \mathrm{C} \mathrm{d}^{-1} \mathrm{~kg}^{-1} \mathrm{C}$ ) and $\mathrm{CH}_{4}$ production ( $788 \mathrm{mg} \mathrm{C} \mathrm{d}^{-1} \mathrm{~kg}^{-1} \mathrm{C}$ ) were observed in a new sediment layer that accumulated over the 2.5 years since the site was flooded. This new sediment layer was characterized by overall low $\mathrm{C}$ content, but represented a mixture of sand and relatively easily decomposable plant litter from reed canary grass killed by flooding. Samples that excluded this new sediment layer but included intact roots remaining from flooded grasses had specific rates of $\mathrm{CO}_{2}\left(\max .28 \mathrm{mg} \mathrm{C} \mathrm{d}^{-1} \mathrm{~kg}^{-1} \mathrm{C}\right)$ and $\mathrm{CH}_{4}$ (max. $34 \mathrm{mg} \mathrm{Cd}^{-1} \mathrm{~kg}^{-1} \mathrm{C}$ ) production that were
\end{abstract}

Correspondence to: M. Hahn-Schöfl (maria.hahn@yahoo.de)
10-20 times lower than for the new sediment layer and were comparable to those of a newly flooded upper peat layer. Lowest rates of anaerobic $\mathrm{CO}_{2}$ and $\mathrm{CH}_{4}$ production (range of 4-8 $\mathrm{mg} \mathrm{Cd}^{-1} \mathrm{~kg}^{-1} \mathrm{C}$ and $<1 \mathrm{mg} \mathrm{Cd}^{-1} \mathrm{~kg}^{-1} \mathrm{C}$ ) were observed when all fresh organic matter sources (plant litter and roots) were excluded. In conclusion, the presence of fresh organic substrates such as plant and root litter originating from plants killed by inundation has a high potential for $\mathrm{CH}_{4}$ production, whereas peat without any fresh plant-derived material is relatively inert. Significant anaerobic $\mathrm{CO}_{2}$ and $\mathrm{CH}_{4}$ production in peat only occurs when some labile organic matter is available, e.g. from remaining roots or root exudates.

\section{Introduction}

Peatlands are recognized as a key player in the atmospheric greenhouse gas (GHG) budget. Although only covering $\sim 3 \%$ of the total land area, the carbon accumulated in peatlands corresponds to almost half of the total atmospheric $\mathrm{C}$ stock (Houghton et al., 1990; Gorham, 1991). Natural peatlands act as sinks for atmospheric $\mathrm{CO}_{2}$ and as sources of the methane $\left(\mathrm{CH}_{4}\right)$, which has a higher global warming potential than $\mathrm{CO}_{2}$. The net climate impact of natural peatlands in Europe is nearly zero (Drösler et al., 2008). Drainage of peatland, e.g. for agricultural use, forestry or for peat extraction, turns peatlands from long-term sinks to significant sources of $\mathrm{CO}_{2}$, while $\mathrm{CH}_{4}$ emissions cease. This leads to a dramatic increase in the net climate impact (Drösler et al., 2008; Augustin, 2001; Nykänen et al., 1998; Alm et al., 2007). In 2007, drained German peatlands used as cropland and

Published by Copernicus Publications on behalf of the European Geosciences Union. 
grassland emitted about 24000 and $13000 \mathrm{Gg} \mathrm{CO}_{2}$, respectively, corresponding to approximately $3 \%$ and $2 \%$ of total anthropogenic $\mathrm{CO}_{2}$ emissions in Germany (Umweltbundesamt, 2009). Furthermore, long-term drainage and agricultural use of peatlands cause irreversible chemical and physical changes in peat characteristics, a loss of organic carbon and concurrently internal eutrophication of the peat soils (Zak et al. 2008).

Peatland restoration via rewetting (inundation), i.e. by raising the local groundwater table, is currently being implemented in Germany with the explicit goal of reducing GHG emissions (Höper et al., 2008). Rewetting principally reduces $\mathrm{CO}_{2}$ emissions but can often lead to a sharp increase in $\mathrm{CH}_{4}$ release, as confirmed by field studies in fen (Hendriks et al., 2007; Wilson et al., 2008) and bog ecosystems (Tuittila et al., 2000; Drösler, 2005).

Extremely high $\mathrm{CH}_{4}$ emissions were observed in a flooded fen grassland in NE Germany (up to $205 \mathrm{~g} \mathrm{C} \mathrm{m}^{-2} \mathrm{yr}^{-1}$ ) in the years following flooding. Contrary to expectations, in this location the net climate impact after flooding was even higher than under drained conditions as the ecosystem did not immediately return to its long-term $\mathrm{CO}_{2}$ sink function (Chojnicki et al., 2007; Höper et al., 2008). As yet, the reason for the excessive $\mathrm{CH}_{4}$ release and the weak $\mathrm{CO}_{2}$ sink function of this flooded fen grassland is not known. However, precise knowledge of these processes is needed to predict if and when a reduction of the expected net climate impact will take place and to propose optimized rewetting measures.

A possible source of the high $\mathrm{CH}_{4}$ production and cause of the weak $\mathrm{CO}_{2}$ sink function after flooding could be the rapid anaerobic decomposition of organic matter in the nutrientrich upper part of the peat layer. It has previously been shown that this layer releases large quantities of nutrients and dissolved organic carbon once waterlogged conditions have been re-established in peat (Zak and Gelbrecht, 2007). Furthermore, primary production and the deposition of plant litter in the top layer may increase $\mathrm{CH}_{4}$ emissions under anoxic conditions (Tuittila et al., 2000; Juutinen et al., 2003; Wilson et al., 2008), as labile organic matter is a prerequisite for anaerobic $\mathrm{CO}_{2}$ and $\mathrm{CH}_{4}$ formation (Glatzel et al., 2004; Segers, 1998; Conrad, 1989). Raising the water table not only affects GHG exchange but also the vitality and composition of the vegetation (Drösler, personal communication; Clymo, 1984). On the above-mentioned fen grassland in NE Germany, the vegetation, which was dominated by reed canary grass (Phalaris arundinacea), died back during the first year of inundation and mixed with sand to form a new sediment layer with a high content of relatively fresh plant litter.

Therefore, we hypothesize that fresh plant litter as a major component of the newly formed sediment can account for a large proportion of the major $\mathrm{CH}_{4}$ emissions and reduced $\mathrm{CO}_{2}$ sink strength as a result of increased $\mathrm{CO}_{2}$ formation. The aim of this study was to quantify the anaerobic $\mathrm{CO}_{2}$ and $\mathrm{CH}_{4}$ production potential of different organic substrates from this highly degraded fen under rewetted condi- tions. Two incubation experiments were performed to show how GHG emissions differ in pure peat and peat with root litter, compared to the newly formed sediment layer, while also taking pore water chemistry into account. On the basis of the incubation experiments, the risk of high $\mathrm{CO}_{2}$ and $\mathrm{CH}_{4}$ emissions in inundated degraded fen grasslands can be assessed.

\section{Material and methods}

\subsection{Site description}

The sampling site "Polder Zarnekow" is located in the valley of the river Peene, $8 \mathrm{~km}$ west of the town Demmin (Mecklenburg-Vorpommern, NE Germany; $53^{\circ} 52.5^{\prime} \mathrm{N}$, $12^{\circ} 52.3^{\prime} \mathrm{E}$ ). The climate is moderately continental temperate with a mean annual air temperature of $8.5^{\circ} \mathrm{C}$ and a mean annual precipitation of $544 \mathrm{~mm}$. The mean daily temperature is $-0.8^{\circ} \mathrm{C}$ in January and $16.7^{\circ} \mathrm{C}$ in July (Teterow meteorological station, $24 \mathrm{~km}$ south-west of the sampling site). The fen is characterized as a river valley mire system with percolation mires dominated by groundwater flow (Joosten and Succow, 2001).

Drainage of these areas began in the early 18th century and was strongly intensified at the end of the 1960s for agricultural use as intensive grassland (Lenschow et al., 2003). In October 2004, the site was rewetted in the course of an EU-funded conservation project. Since then, field measurements of gas exchange have been performed at this site (see introduction and discussion). Due to substantial peat loss and shrinkage, the Zarnekow polder now appears as a shallow lake permanently inundated with a water level of about +0.1 to $+0.5 \mathrm{~m}$ (Zak and Gelbrecht, 2007). The subjacent peat layer is up to $10 \mathrm{~m}$ thick. Due to peat mineralization during decades of drainage, the upper $0.3 \mathrm{~m}$ approximately can be classified as highly decomposed peat (H 10) according to the von Post scale (Puustjärvi, 1970), however, since the soil material is strongly mineralized they are also called "muck-soils" (Okruszko, 1995). Below, slightly to moderately decomposed peat (H 3 to 6) can be found which has either not been affected by the drainage or has been only slightly affected. Long-term drainage and previous agricultural use led to a loss of organic carbon (due to peat oxidation) and, therefore, to an enrichment of $\mathrm{P}$ and $\mathrm{N}$ with decreasing molar ratios of $\mathrm{C}: \mathrm{P}$ and $\mathrm{C}: \mathrm{N}$ in upper soil layers (Zak and Gelbrecht 2007). Concurrently, organic bound $\mathrm{P}$ and $\mathrm{N}$ was transformed into labile inorganic forms (peat mineralization) supporting the internal eutrophication of the peat soils (Zak et al. 2008).

The former grassland vegetation, dominated by reed canary grass (Phalaris arundinacea), died back during the first year of inundation. Since the second year of inundation, the water body of the shallow lake has been dominated by water plants like Ceratophyllum and Lemna sp. adapted to 
Table 1. Selected peat characteristics for peat from different horizons, as well as sediment/peat substrates incubated in two experiments sampled from the Zarnekow polder (mean, $n=3$ ).

\begin{tabular}{|c|c|c|c|c|c|c|c|c|}
\hline & $\begin{array}{c}\text { Peat layers } \\
(\mathrm{m})\end{array}$ & $\begin{array}{c}\mathrm{dbd} \\
\left(\mathrm{g} \mathrm{cm}^{-3}\right)\end{array}$ & $\mathrm{H}^{\mathrm{c}}$ & $\begin{array}{c}\mathrm{OM}^{\mathrm{d}} \\
(\%)\end{array}$ & $\begin{array}{l}\mathrm{C}^{\mathrm{e}} \\
(\%)\end{array}$ & $\begin{array}{l}\mathrm{N}^{\mathrm{e}} \\
(\%)\end{array}$ & $\mathrm{C}: \mathrm{N}^{\mathrm{e}}$ & $\mathrm{C}: \mathrm{P}$ \\
\hline \multicolumn{9}{|c|}{ Peat layer incubation } \\
\hline Upper peat layer & -0.1 to -0.2 & $0.30^{\mathrm{a}}$ & 10 & 76 & 40 & 3.4 & 12 & 320 \\
\hline Middle peat layer & -0.5 to -0.6 & $0.18^{\mathrm{a}}$ & 6 & 84 & 44 & 2.8 & 16 & 720 \\
\hline Lower peat layer & -1.0 to -1.2 & $0.12^{\mathrm{a}}$ & 3 & 89 & 48 & 2.7 & 18 & 1550 \\
\hline \multicolumn{9}{|c|}{ Organic substrate incubation } \\
\hline \multirow[t]{2}{*}{ Organic sediment } & +0.05 to +0.3 & $0.2^{\mathrm{b}}$ & - & 40 & $13(s)$ & $1.1(\mathrm{~s})$ & $11(\mathrm{~s})$ & - \\
\hline & & & & & $44(\mathrm{p})$ & $1.4(\mathrm{p})$ & $32(\mathrm{p})$ & \\
\hline \multirow[t]{2}{*}{ "Peat with roots" } & -0.05 to -0.2 & $0.4^{\mathrm{b}}$ & 10 & 28 & $16(s)$ & $1.4(\mathrm{~s})$ & $11(\mathrm{~s})$ & - \\
\hline & & & & & $44(\mathrm{p})$ & $1.2(\mathrm{p})$ & $38(\mathrm{p})$ & \\
\hline "Peat only" & -0.1 to -0.2 & $0.3^{\mathrm{b}}$ & 10 & 76 & 39.8 & 3.5 & 11 & - \\
\hline
\end{tabular}

a Dry bulk density from Zak and Gelbrecht (2007).

b Dry bulk density estimated.

c Degree of peat decomposition according to von Post-scale (Puustjärvi, 1970; Zak and Gelbrecht, 2007).

d Organic matter in $\%$ of dry weight determined by loss of ignition.

e Organic substrate incubation: C- and N-content were determined separately for (s) sediment/peat substrate ( $<2 \mathrm{~mm}$ fraction) and (p) plant material.

high nutrient concentrations. An organic sediment layer up to $0.3 \mathrm{~m}$ thick was formed at the bottom of the shallow lake with a high content of relatively fresh organic matter from the dying-off of plants. Under the prevailing eutrophic and inundated conditions, the substrate pool is assumed to be continuously refilled by litter from submerged macrophytes and helophytes from the nearby littoral zone.

\subsection{Incubation experiments}

Two different incubation experiments under simulated flooding were performed to elucidate the impact of different organic substrates on GHG emissions. In the first experiment, peat from different soil depths was incubated (hereafter peat layer incubation) (see Table 2). The second experiment (hereafter organic substrate incubation) focused on three kinds of organic substrates taken from the uppermost layer of the peat. These substrates differed in the amount of fresh plant litter or roots present and in the time elapsed since the flooding of the wetland. In both experiments temperature was kept constant and the anaerobic production potential for $\mathrm{CO}_{2}$ and $\mathrm{CH}_{4}$ as well as pore water chemistry were investigated. An overview of selected characteristics of the incubated substrates, including chemical data, is given in Table 1 .

\subsubsection{Peat layer incubation: experimental set up and chemical analysis}

Peat samples were extracted by spade in August 2004 (prior to rewetting on site) from three successive, superimposed soil horizons: upper peat layer (from -0.1 to $-0.2 \mathrm{~m}$ depth), middle peat layer (from -0.5 to $-0.6 \mathrm{~m}$ ), and lower peat layer (from -1.0 to $-1.2 \mathrm{~m}$ ) ( 3 replicates each). The ground- water level at the time of sampling was lower than the deepest sampling depth. Consequently, we assume that aerobic conditions were present for all samples taken from different soil depths. Visible fresh roots were removed by hand from the upper peat layer during peat homogenization. However, it was impossible to remove all fresh plant-derived material. As the upper peat layer was the rooting zone of the grassland vegetation, it can be assumed that some fresh organic matter e.g. from rhizodeposition may be present in the peat.

For incubation, water-tight PVC boxes $(0.6 \mathrm{~m} \times 0.4 \mathrm{~m} \times$ $0.4 \mathrm{~m} ; 96 \mathrm{~L}$ ) were used. The incubation vessels were filled with $\sim 40 \mathrm{~kg}$ mixed peat samples from the different horizons $\left(0.2 \mathrm{~m}\right.$ high, $\left.\sim 0.05 \mathrm{~m}^{3}\right)$. For experimental rewetting of the peat, $3.4 \mathrm{mM}$ sodium chloride solution, equivalent to the average ionic strength of the fen-feeding groundwater, was added. To ensure water-saturated conditions throughout the experiment, the water level was kept $5 \mathrm{~cm}$ above the peat surface, and evaporation loss was replaced with deionized water. Incubation lasted for 363 days in a climate chamber at a constant temperature of $20 \pm 1^{\circ} \mathrm{C}$ under dark conditions to avoid algae growth. The incubation vessels were kept open to the atmosphere except during the brief intervals when gas fluxes were measured.

The rates of $\mathrm{CO}_{2}$ and $\mathrm{CH}_{4}$ emitted from the various substrate surfaces were determined using the closed chamber method, measuring the concentration change in the headspace over time (Schinner, 1993). For this purpose, the incubation vessels were closed for one hour by gas-tight lids equipped with plugs for gas sampling. Gas samples were taken from the headspace using evacuated glass flasks $(100 \mathrm{~mL})$ at $0,0.5$ and $1 \mathrm{~h}$ and were analyzed by the gas chromatograph (GC 145, Shimadzu) (Loftfield et al., 1997). We 
Table 2. Overview of the two incubations performed.

\begin{tabular}{|c|c|c|}
\hline & Peat layer incubation & Organic substrate incubation \\
\hline Duration & 363 days & 53 days \\
\hline $\begin{array}{l}\text { Substrates incubated } \\
\text { ( } 3 \text { replicates each) }\end{array}$ & $\begin{array}{l}\text { Peat taken from different depths (upper, middle } \\
\text { and lower peat layer) }\end{array}$ & $\begin{array}{l}\text { Upper peat layer with differing quality } \\
\text { of plant litter (organic sediment, } \\
\text { "peat with roots", "peat only") }\end{array}$ \\
\hline Incubation conditions & $\begin{array}{l}20 \pm 1^{\circ} \mathrm{C} \\
\text { no light, water stagnant conditions }\end{array}$ & $\begin{array}{l}15 \pm 1^{\circ} \mathrm{C} \\
\text { no light, water stagnant conditions }\end{array}$ \\
\hline Incubation vessels & $\begin{array}{l}\text { Open PVC-boxes }(0.6 \times 0.4 \times 0.4 \mathrm{~m}) \text { with closure } \\
\text { lid for gas exchange measurement }\end{array}$ & $\begin{array}{l}\text { Continuously closed PVC-columns } \\
(d=0.15 \mathrm{~m}, h=0.35 \mathrm{~m})\end{array}$ \\
\hline Substrate volume & $h=0.2 \mathrm{~m}, V=0.05 \mathrm{~m}^{3}$ & $h=0.27 \mathrm{~m}, V=0.005 \mathrm{~m}^{3}$ \\
\hline $\begin{array}{l}\text { Measurement of gas } \\
\text { fluxes }\end{array}$ & $\begin{array}{l}\mathrm{CO}_{2} \text { and } \mathrm{CH}_{4} \text { emission from surface (every two } \\
\text { weeks/monthly, closed chamber method) }\end{array}$ & $\begin{array}{l}\mathrm{CO}_{2} \text { and } \mathrm{CH}_{4} \text { emission from surface } \\
\text { (continuously, flow-through system) }\end{array}$ \\
\hline $\begin{array}{l}\text { Determination of gas } \\
\text { concentrations in } \\
\text { pore water }\end{array}$ & - & $\begin{array}{l}\mathrm{CO}_{2} \text { and } \mathrm{CH}_{4} \text { concentration in } \\
\text { silicone probes (every } 1-11 \text { days) }\end{array}$ \\
\hline $\begin{array}{l}\text { Analysis of pore } \\
\text { water chemistry }\end{array}$ & $\begin{array}{l}\mathrm{pH} \text {, redox potential, soluble reactive phosphorus } \\
(\mathrm{SRP}), \mathrm{NH}_{4}-\mathrm{N}, \mathrm{SO}_{4}^{2-}, \mathrm{Fe}, \mathrm{Ca} \text {, dissolved inorganic } \\
\text { and organic carbon (DIC, DOC) concentrations in } \\
\text { pore water (at beginning and end of incubation) }\end{array}$ & $\begin{array}{l}\mathrm{pH}, \text { redox potential, soluble reactive } \\
\text { phosphorus (SRP), Fe and } \mathrm{Ca} \\
\text { concentrations in pore water } \\
\text { (at end of incubation) }\end{array}$ \\
\hline
\end{tabular}

assumed linearity. Sampling was done every two weeks for the first 8 weeks and monthly thereafter.

Emission rates of $\mathrm{CO}_{2}$ and $\mathrm{CH}_{4}$ related to carbon content of the peat substrate and time $\left(\mathrm{mg} \mathrm{C} \mathrm{d}^{-1} \mathrm{~kg}^{-1} \mathrm{C}\right)$ were calculated according to Eq. (1):

emission rate $=\frac{M \times p \times V}{R \times T \times A} \times \frac{d c}{d t} \times \frac{1}{\mathrm{Ct}}$

in which $M$ is the atomic mass of carbon, $p$ is the air pressure, $V$ the volume of the headspace, $R$ the gas constant, $T$ the temperature, $A$ the area of the incubation vessel, $d c$ the difference of gas concentrations, $d t$ the time interval between gas sampling, and $\mathrm{Ct}$ is the carbon content of the peat substrate.

For the analysis of pore water chemistry, rechargeable dialysis samplers were used, as described in detail by Zak and Gelbrecht (2007). Briefly, the one-chamber-sampler $(\sim 0.05 \mathrm{~L})$ was adjusted in the peat at $1-11 \mathrm{~cm}$ depth at the beginning of the incubation experiment. For sampling, the chamber water was completely removed with a pipette and directly renewed by oxygen-free deionized water in order to avoid oxygen input into the anoxic peat. Sampling was done every two weeks for the first 8 weeks and monthly thereafter over the 363-day incubation period. To prevent oxidation and subsequent precipitation of redox-sensitive substances, pore water samples were taken quickly and stabilized with hydrochloric acid $(2 \mathrm{M} \mathrm{HCl})$. Pore water $\mathrm{pH}$ was determined using a $\mathrm{pH}$ probe (WTW), the redox potential by a Pt electrode with $\mathrm{Ag} / \mathrm{AgCl}$ reference electrode, and measured values were adjusted to standard hydrogen potential and $\mathrm{pH}$ of
7. Soluble reactive phosphorus (SRP) was analyzed photometrically by the molybdenum blue method, $\mathrm{NH}_{4}-\mathrm{N}$ was determined photometrically by the indophenol method. Fe and $\mathrm{Ca}$ concentrations in the pore water were analyzed by flame atomic absorption spectrometry and sulfate concentrations by ion chromatography. DIC and DOC were measured with a C-Analyzer. Further details on fixation of anoxic pore water samples and chemical analysis can be found in Zak and Gelbrecht (2007).

\subsubsection{Organic substrate incubation: experimental set up and chemical analysis}

Three different organic substrates were investigated: (1) organic sediment formed post-flooding (from fragmented fresh roots and leaves, which had accumulated to a thickness of up to $0.3 \mathrm{~m}$ above the original fen surface over a period of 2.5 years), (2) a highly decomposed peat with intact Phalaris arundinacea roots taken from -0.05 to $-0.2 \mathrm{~m}$ depth (hereafter "peat with roots"), and (3) a highly decomposed peat without any fresh plant material taken from -0.1 to $-0.2 \mathrm{~m}$ depth and with roots removed (hereafter "peat only"). Samples were taken from the same location as for the peat layer incubation in April 2007 (2.5 years after rewetting). The soil depths given refer to the soil surface prior to rewetting to be comparable. Organic sediment and "peat only" were sampled by inserting a plexiglass tube $(d=0.13 \mathrm{~m})$ into the lake bottom, removing the supernatant lake water and obtaining the desired organic substrate. "Peat with roots" was extracted by spade from a place with no overlying organic 
sediment and removal of the upper $0.05 \mathrm{~m}$ in order to exclude living above-ground plant material. All three substrates were taken from locations under water-saturated soil conditions and therefore we assume that conditions were anaerobic at the start of the subsequent incubation. Each of the three organic substrates was mixed for several minutes by hand and put into the PVC incubation vessels $(h=0.35 \mathrm{~m}, d=0.15 \mathrm{~m}$, substrate $0.27 \mathrm{~m}$ high, $\sim 0.005 \mathrm{~m}^{3}, 3$ replicates each). Subsamples of the substrates were taken directly after sampling for chemical characterization (see below). Multi-chamber dialysis samplers were inserted into the upper $10 \mathrm{~cm}$ of the soil columns to investigate pore water chemistry (for details see Zak et al., 2010). In addition, silicone probes were inserted at a depth of approximately $0.23 \mathrm{~m}$ in the substrate to determine gas concentrations within the substrates (see below). Lake water from the sampling site was added until the substrates were completely covered in order to maintain anaerobic conditions. The incubation vessels were closed with gas-tight lids equipped with ports for gas measurements and incubated at a constant temperature of $15 \pm 1^{\circ} \mathrm{C}$ under dark conditions for 53 days.

The carbon dioxide and methane fluxes from the sediment or peat substrates were determined with a steady state flowthrough chamber system combined with automated gas analysis equipment. A constant air flow of $6 \times 10^{-3} \mathrm{~m}^{3} \mathrm{~h}^{-1}$ was adjusted in the open headspace of the incubation vessels. The measurements of the inflow/outflow (ambient air/headspace air) concentrations was carried out continuously over the entire incubation period. The gas concentrations were analyzed by a photoacoustic infra-red multi-gas monitor (INNOVA 1312, INNOVA AirTech Instruments, Ballerup, Denmark). Since the gas monitor does not fully compensate for crossinterference of $\mathrm{CH}_{4}$ and water vapour at high concentrations, the air was partially dried at $5{ }^{\circ} \mathrm{C}$ by a gas conditioning system (Rosemount) to reduce water vapour concentrations before measurement. The measurement frequency was three times per hour per incubation vessel with three replications each.

Gas fluxes related to carbon content of the sediment or peat substrate and time $\left(\mathrm{mg} \mathrm{Cd}^{-1} \mathrm{~kg}^{-1} \mathrm{C}\right)$ were calculated according to Eq. (2):

emission rate $=\frac{M \times p \times v}{R \times T \times A} \times \frac{d c}{\mathrm{Ct}}$

in which $M$ is the atomic mass of carbon, $p$ is the air pressure, $v$ the air flow, $R$ the gas constant, $T$ the temperature, $A$ the area of the incubation vessel, $d c$ the difference of gas concentrations, and $\mathrm{Ct}$ is the carbon content of the peat substrate.

As a further indicator for the intensity of the gas production processes, $\mathrm{CO}_{2}$ and $\mathrm{CH}_{4}$ concentrations in the pore water of the substrates were determined using adapted silicone probes according to Kammann et al. (2001). A silicone probe consisted of a curled-up silicone tube $(\mathrm{OD}=8 \mathrm{~mm}$, $\mathrm{ID}=6 \mathrm{~mm}, L=1.0 \mathrm{~m}$ ) connected with a stainless steel capil- lary tube $(\mathrm{OD}=1.6 \mathrm{~mm}, \mathrm{ID}=0.75 \mathrm{~mm}, L=0.32$ and $0.21 \mathrm{~m})$ and a 3-port-valve at each end as well as an injection port at one end. Gas exchange takes place between the interior space of the probe and the substrate only by diffusion through the walls of the silicone tube until equilibrium is reached. Gases within the silicone tube reached $95 \%$ equilibrium with the surrounding atmosphere within several hours (Kammann et al., 2001).

For sampling, the air in the silicone tube was moved to the end with the injection port by inserting water into the silicone probe and taking a gas sample using a gas-tight syringe. Silicone probe samples were diluted with $\mathrm{N}_{2}$ to concentrations which were in the measurement range of the GC, filled into evacuated $100 \mathrm{ml}$ glass flasks and analyzed with the gas chromatograph (Shimadzu GC-14B, ECD for $\mathrm{CO}_{2}$, FID for $\mathrm{CH}_{4}$ ) (Loftfield et al., 1997). After sampling, the water and air in the silicone probes were removed and the probes flushed with $\mathrm{N}_{2}$ to ensure anaerobic conditions. Samples were taken in 1 to 11 days intervals.

For the analysis of pore water chemistry, the dialysis samplers were removed at the end of incubation, cleaned with deionized water, and the water of the soil chambers was obtained using pipettes. The pore water was analyzed for $\mathrm{pH}$, redox potential, soluble reactive phosphorus (SRP) and $\mathrm{Fe}$ and $\mathrm{Ca}$ concentrations as described above.

For solid $\mathrm{C}$ and $\mathrm{N}$ analysis, subsamples of the substrates were taken prior to incubation, sediment/peat substrates and plant material were separated by sieving $(2 \mathrm{~mm})$, dried at $40^{\circ} \mathrm{C}$ (sediment/peat substrate) or $70^{\circ} \mathrm{C}$ (plant material) for 5 days, ground and then analyzed (Elementar $\mathrm{CN}$ analyzer vario MAX; combustion at $1100^{\circ} \mathrm{C}$; thermal conductivity detector). Measured solid $\mathrm{C}$ and $\mathrm{N}$ values for the sediment/peat substrates were corrected for water content when dried at $105^{\circ} \mathrm{C}$.

\subsection{Statistics}

Repeated measures analysis of variance by fitting linear mixed-effects models with Tukey post-hoc comparisons were performed with R 2.10.0 ( $R, 2009)$ to compare the time series of gas emissions (significance level of $p<0.001$ ). SPSS 17.0 was used for one-way ANOVA and Tukey posthoc comparisons to compare means of pore water chemistry analysis and cumulative gas fluxes (significance level of $p<0.05$ ).

\section{Results}

\subsection{Peat layer incubation}

The lowest carbon content and the highest nitrogen and phosphorus contents were found in the uppermost peat layer compared to underlying peat samples (see Table 1). Consequently, lowest $\mathrm{C}: \mathrm{N}$ and $\mathrm{C}: \mathrm{P}$ ratios - both indicators for substrate degradability - were observed in the upper peat layer 


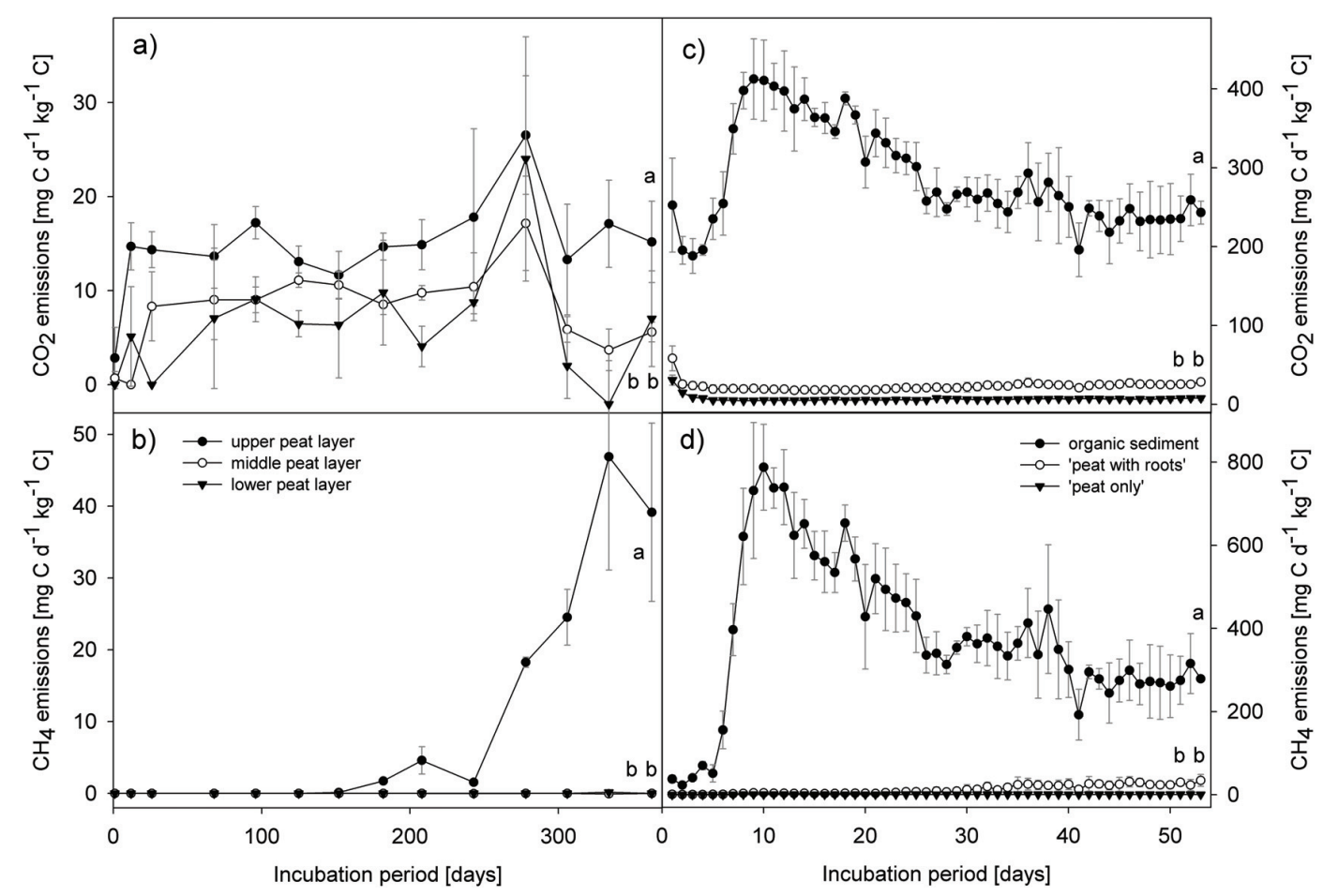

Fig. 1. $\mathrm{CO}_{2}$ and $\mathrm{CH}_{4}$ emissions from the surface for the peat layer incubation $(\mathbf{a}, \mathbf{b})$ and for the organic substrate incubation $(\mathbf{c}, \mathbf{d})$ at constant temperature $\left(20^{\circ} \mathrm{C}\right.$ and $\left.15^{\circ} \mathrm{C}\right)$ (mean $\pm \mathrm{SD}, n=3$; different letters on the left indicate significant differences, $\left.p<0.001\right)$.

(12 and 320), whereas the lower peat layer had the highest values (18 and 1550).

In accordance with the peat characteristics, peat samples from different horizons differed significantly in their $\mathrm{CO}_{2}$ emissions $\left(F_{2,6}=12.6, p=0.0072\right)$. Anaerobic $\mathrm{CO}_{2}$ production was highest $(p<0.001)$ at the top of the soil profile. A strong increase in $\mathrm{CO}_{2}$ production in the upper peat layer was found during the first 14 incubation days and, after approximately 150 days, emission rates increased until day 278 (see Fig. 1a). Anaerobic $\mathrm{CO}_{2}$ production in the middle peat layer was lower than in the upper peat layer but little higher than in the lower peat layer. In the middle peat layer, an increase in anaerobic $\mathrm{CO}_{2}$ production was detected two weeks later than in the upper peat layer. It stayed relatively stable thereafter and decreased at the end of incubation. In the lower peat layer, anaerobic $\mathrm{CO}_{2}$ production showed some fluctuations over the entire incubation period. The cumulative $\mathrm{CO}_{2}$ fluxes over 363 days for the incubation of the material from the upper peat layer were 1.7 times higher than for the incubation of the material from the middle peat layer and 2.3 times higher than for the incubation of the material from the lower peat layer (see Table 4).

$\mathrm{CH}_{4}$ emissions from the middle and lower peat layer were zero over the entire incubation period. The upper peat layer emitted no $\mathrm{CH}_{4}$ until day 152. From day 243 onwards, $\mathrm{CH}_{4}$ emissions increased strongly and reached a plateau at the end of incubation (maximum of $46.9 \mathrm{mg} \mathrm{C} \mathrm{d}^{-1} \mathrm{~kg}^{-1} \mathrm{C}$ ) (see Fig. 1b). Cumulative $\mathrm{CH}_{4}$ fluxes over 363 days were $3.4 \mathrm{~g} \mathrm{C} \mathrm{kg}^{-1} \mathrm{C}$ in the upper peat layer and around zero for the middle and lower peat layer.

During the 363 incubation days, a small fraction of the initial $\mathrm{C}$ in the soil organic matter was respired as $\mathrm{CO}_{2}$ or $\mathrm{CH}_{4}$ (Table 4), e.g. from the upper peat layer only $0.55 \%$ and $0.4 \%$ of the initial $\mathrm{C}$ were respired as $\mathrm{CO}_{2}$ and $\mathrm{CH}_{4}$.

The experimental rewetting caused a reduction in the redox potential and an increase in $\mathrm{pH}$ in all treatments (see Table 3). Sulfate concentrations were generally high at the beginning of the rewetting period. In the upper peat layer, sulfate concentrations decreased rapidly during the first weeks of incubation and stayed around $0.1 \mathrm{mM}$ after day 125 (see Fig. 3). Sulfate concentrations decreased slowly in the middle peat layer but increased in the lower peat layer over the entire incubation period. Fe concentrations increased strongly in the upper peat layer and to a much smaller extent in the middle peat layer. In the lower peat layer, Fe concentrations in the pore water were low overall and showed only a marginal increase over time. The highest concentrations of soluble reactive phosphorus (SRP), ammonium, dissolved inorganic and organic carbon, and calcium were generally found in the pore water of the upper peat layer. These concentrations were 2 to 200 times higher than in underlying peat (Table 3, for single results see Zak and Gelbrecht, 2007). 


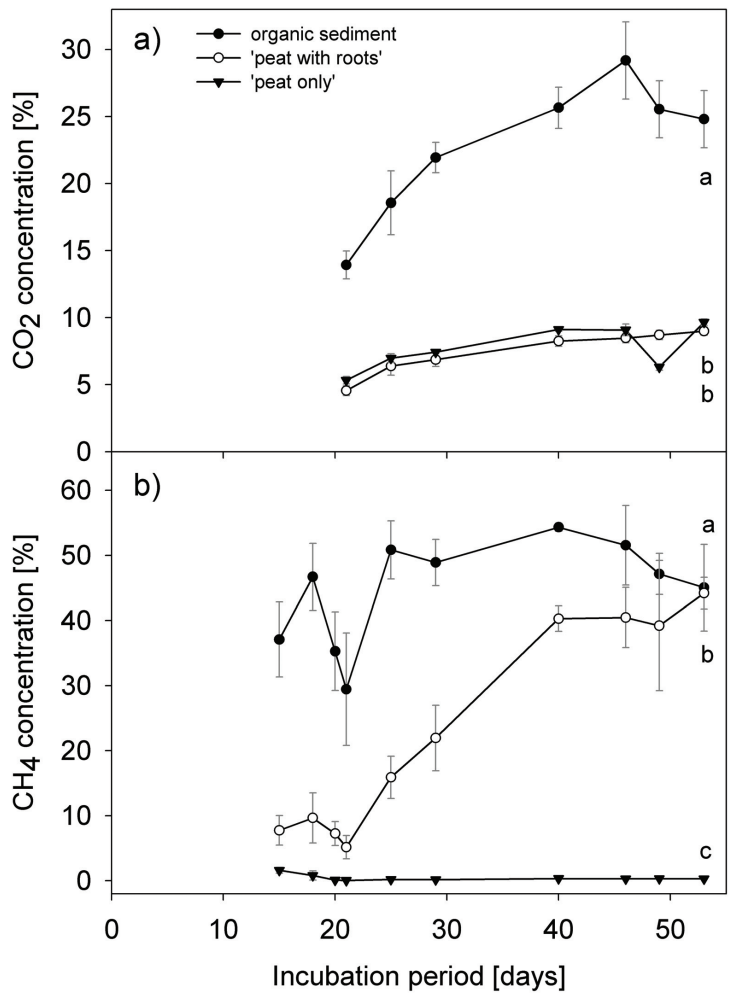

Fig. 2. Organic substrate incubation: $\mathrm{CO}_{2}$ (a) and $\mathrm{CH}_{4}$ (b) concentrations in the silicone probes over a 53-day period at constant temperature of $15^{\circ} \mathrm{C}$ (mean $\pm \mathrm{SD}, n=3$ ). Three organic substrates (organic sediment, "peat with roots" and "peat only") taken from the uppermost peat layer are compared (different letters indicate significant differences, $p<0.001,1 \%=10000 \mathrm{ppm}$ ).

\subsection{Organic substrate incubation}

The $\mathrm{C}$ and $\mathrm{N}$ content were determined separately for the $<2 \mathrm{~mm}$ fraction of the sediment/peat and the plant material. The $\mathrm{C}$ content of the sediment/peat was surprisingly low in the organic sediment and in the "peat with roots" but three times higher in the "peat only" (see Table 1). This fact was explained by sand present in the organic sediment and "peat with roots" samples. The sand intrusion is due to erosion from an adjacent bank built for agricultural machinery. All three sediment/peat substrates had similar C:N ratios, those of the plant material in the organic sediment and the "peat with roots" were three times higher (Table 1).

The differences in $\mathrm{CO}_{2}$ emissions between the three sediment/peat substrates were much more pronounced than for the peat layer incubation $\left(F_{2,6}=600.5, p<0.0001\right.$, see Fig. 1c). Anaerobic $\mathrm{CO}_{2}$ production was highest in the organic sediment, with a strong increase at the beginning of incubation (maximum of $412 \mathrm{mg} \mathrm{Cd}^{-1} \mathrm{~kg}^{-1} \mathrm{C}$ ) and a continuous decline after day $8 . \mathrm{CO}_{2}$ production in the "peat with roots" was more than 10 times lower than in the organic sediment $(p<0.001)$ and increased slowly over the incubation period (range of $17-28 \mathrm{mg} \mathrm{C} \mathrm{d}^{-1} \mathrm{~kg}^{-1} \mathrm{C}$ ). In the "peat only",

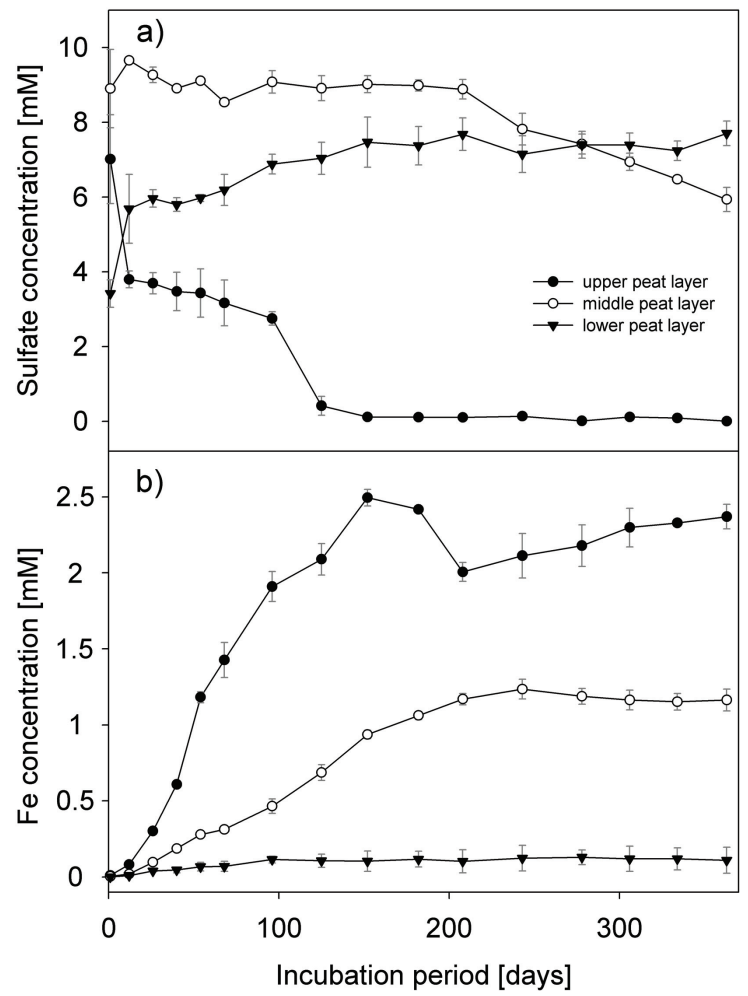

Fig. 3. Peat layer incubation: Sulfate (a) and iron (b) concentrations in the pore water of the upper, middle and lower peat layer over the 363-day incubation period (mean $\pm \mathrm{SD}, n=3$ ).

$\mathrm{CO}_{2}$ emissions were even lower than in the freshly rewetted upper peat layer of the peat profile incubation and stayed in the range of $4-8 \mathrm{mg} \mathrm{C} \mathrm{d}^{-1} \mathrm{~kg}^{-1} \mathrm{C}$ over the entire incubation period. Cumulative $\mathrm{CO}_{2}$ fluxes for 53 days were one order of magnitude higher in the organic sediment than in the "peat with roots" and the "peat only" (see Table 4).

$\mathrm{CO}_{2}$ concentrations in the substrate pore water sampled via silicone probes (see Fig. 2) were high in all substrates. The release of gas bubbles was observed on several sampling occasions. Analogous to gas emissions from the surface, $\mathrm{CO}_{2}$ concentrations were significantly higher in the organic sediment and increased strongly over the incubation period until day 46 (up to $29 \%$ ), with a decrease thereafter. The $\mathrm{CO}_{2}$ concentrations in "peat with roots" and "peat only" did not differ significantly and increased slowly over time (up to approximately $9 \%$ ).

With regard to $\mathrm{CH}_{4}$ production, there were fundamental differences between the three sediment/peat substrates that were incubated (see Fig. 1d). $\mathrm{CH}_{4}$ emissions from the organic sediment were higher compared to the two other substrates and increased strongly from day 6 , reaching a maximum on day $10\left(788 \mathrm{mg} \mathrm{C} \mathrm{d}^{-1} \mathrm{~kg}^{-1} \mathrm{C}\right)$, followed by a continuous decrease until the end of incubation. In contrast, the "peat with roots" showed low $\mathrm{CH}_{4}$ emissions until day 7 and increased slowly thereafter to a maximum of $34 \mathrm{mg} \mathrm{C} \mathrm{d}^{-1} \mathrm{~kg}^{-1} \mathrm{C}$ at the end of incubation. Thus, the same 
Table 3. Characterization of pore water chemistry for the peat layer incubation and the organic substrate incubation (letters indicate differences between the treatments, $p<0.05)$.

\begin{tabular}{|c|c|c|c|c|c|c|c|c|c|c|c|c|c|c|c|c|c|c|}
\hline \multirow[b]{3}{*}{ Incubation $^{\mathrm{z}}$} & \multirow{2}{*}{\multicolumn{2}{|c|}{$\mathrm{pH}$}} & \multirow{2}{*}{\multicolumn{2}{|c|}{$\begin{array}{c}\text { Redox } \\
\text { potential } \\
E_{7}(\mathrm{~V})\end{array}$}} & \multicolumn{14}{|c|}{ Concentrations in the pore water } \\
\hline & & & & & \multicolumn{2}{|c|}{$\begin{array}{l}\text { SRP } \\
(\mu \mathrm{M})\end{array}$} & \multicolumn{2}{|c|}{$\begin{array}{c}\mathrm{NH}_{4}-\mathrm{N} \\
(\mathrm{mM})\end{array}$} & \multicolumn{2}{|c|}{$\begin{array}{l}\text { Sulfate } \\
(\mathrm{mM})\end{array}$} & \multicolumn{2}{|c|}{$\begin{array}{l}\mathrm{Fe} \\
(\mathrm{mM})\end{array}$} & \multicolumn{2}{|c|}{$\begin{array}{c}\mathrm{Ca} \\
(\mathrm{mM})\end{array}$} & \multicolumn{2}{|c|}{$\begin{array}{l}\text { DIC } \\
(\mathrm{mM})\end{array}$} & \multicolumn{2}{|c|}{$\begin{array}{l}\text { DOC } \\
(\mathrm{mM})\end{array}$} \\
\hline & Start & End & Start & End & Start & End & Start & End & Start & End & Start & End & Start & End & Start & End & Start & End \\
\hline \multicolumn{19}{|c|}{ Peat layer incubation } \\
\hline $\begin{array}{l}\text { Upper peat } \\
\text { layer }\end{array}$ & $6.0^{\mathrm{a}}$ & $6.7^{\mathrm{a}}$ & $0.51^{\mathrm{a}}$ & $0.14^{\mathrm{a}}$ & $0.13^{\mathrm{a}}$ & $144^{\mathrm{a}}$ & $0.02^{\mathrm{a}}$ & $1.86^{\mathrm{a}}$ & $7.01^{\mathrm{a}}$ & $0.00^{\mathrm{a}}$ & 0.01 & $2.37^{\mathrm{a}}$ & $3.43^{\mathrm{a}}$ & $11.9^{\mathrm{a}}$ & $2.80^{\mathrm{a}}$ & $29.2^{\mathrm{a}}$ & $6.58^{\mathrm{a}}$ & $44.4^{\mathrm{a}}$ \\
\hline $\begin{array}{l}\text { Middle peat } \\
\text { layer }\end{array}$ & $5.9^{\mathrm{a}}$ & $6.8^{\mathrm{a}}$ & $0.57^{\mathrm{ab}}$ & $0.17^{\mathrm{b}}$ & $0.13^{\mathrm{a}}$ & $0.48^{\mathrm{b}}$ & $0.02^{\mathrm{a}}$ & $0.35^{\mathrm{b}}$ & $8.90^{\mathrm{a}}$ & $5.93^{\mathrm{b}}$ & 0.00 & $1.16^{\mathrm{b}}$ & $6.93^{\mathrm{b}}$ & $12.1^{\mathrm{a}}$ & $1.42^{\mathrm{b}}$ & $15.1^{\mathrm{b}}$ & $4.69^{\mathrm{b}}$ & $23.2^{\mathrm{b}}$ \\
\hline $\begin{array}{l}\text { Lower peat } \\
\text { layer }\end{array}$ & $5.5^{\mathrm{b}}$ & $6.6^{\mathrm{a}}$ & $0.59^{\mathrm{b}}$ & $0.27^{\mathrm{c}}$ & $0.13^{\mathrm{a}}$ & $0.68^{\mathrm{b}}$ & $0.05^{\mathrm{b}}$ & $0.03^{\mathrm{c}}$ & $3.42^{\mathrm{b}}$ & $7.70^{\mathrm{c}}$ & 0.00 & $0.11^{\mathrm{c}}$ & $4.75^{\mathrm{c}}$ & $6.45^{\mathrm{b}}$ & $0.64^{\mathrm{c}}$ & $0.69^{\mathrm{c}}$ & $1.49^{\mathrm{c}}$ & $1.20^{\mathrm{c}}$ \\
\hline \multicolumn{19}{|c|}{ Organic substrate incubation } \\
\hline $\begin{array}{l}\text { Organic } \\
\text { sediment }\end{array}$ & & $6.7^{\mathrm{a}}$ & & $0.17^{\mathrm{a}}$ & & $1085^{\mathrm{a}}$ & & - & & - & & $0.35^{\mathrm{a}}$ & & $9.06^{\mathrm{a}}$ & & - & & - \\
\hline $\begin{array}{l}\text { "Peat with } \\
\text { roots" }\end{array}$ & & $7.0^{\mathrm{b}}$ & & $0.18^{\mathrm{a}}$ & & $35.7^{\mathrm{b}}$ & & - & & - & & $1.38^{\mathrm{b}}$ & & $9.11^{\mathrm{a}}$ & & - & & - \\
\hline "Peat only" & & $6.9^{\mathrm{a}}$ & & $0.14^{\mathrm{a}}$ & & $129^{c}$ & & - & & - & & $1.50^{\mathrm{c}}$ & & $15.3^{\mathrm{b}}$ & & - & & - \\
\hline
\end{tabular}

${ }^{\mathrm{z}}$ Data given for the peat layer incubation: Start on day 1, End on day 363, further data and details see in Zak and Gelbrecht (2007); in the organic substrate incubation data are available for the end of the incubation (on day 53). Letters a-c indicate significant differences between substrates, $p<0.05$.

level was reached as that found for the upper peat layer in the peat layer incubation (see Fig. 1b), whereas $\mathrm{CH}_{4}$ emissions from "peat only" stayed low over the entire incubation period ( $\left.<1 \mathrm{mg} \mathrm{C} \mathrm{d}^{-1} \mathrm{~kg}^{-1} \mathrm{C}\right)$. Cumulative $\mathrm{CH}_{4}$ fluxes in the organic sediment were $2-3$ orders of magnitude higher than in the "peat with roots" and "peat only" (Table 4).

Fundamental and significant differences between the three organic substrates were also observed for $\mathrm{CH}_{4}$ concentrations in the silicone probes $\left(F_{2,6}=246.1, p<0.0001\right.$, see Fig. 2). $\mathrm{CH}_{4}$ concentrations were highest in the organic sediment where they remained relatively constant after day 25 (range of $45-54 \%$ ). In contrast, in the "peat with roots" $\mathrm{CH}_{4}$ concentrations started low but increased strongly from day 21 onwards until they reached the same level as the organic sediment at the end of incubation. $\mathrm{CH}_{4}$ concentrations in the "peat only" were lower than in the other two organic substrates (maximum of $1.6 \%$ at the start of incubation) and even decreased over the incubation period.

Despite the high gas flux rates from the organic sediment, only $3.5 \%$ of the initial total carbon was respired as either $\mathrm{CO}_{2}$ or $\mathrm{CH}_{4}$ during 53 days of incubation. From "peat with roots" and "peat only" the fraction respired was 1-2 orders of magnitude lower (see Table 4).

Comparing the gas fluxes of the two incubation experiments, the organic sediment emitted most $\mathrm{CO}_{2}$ and $\mathrm{CH}_{4}$ compared to all peat substrates - both peat from different horizons in the peat layer incubation and "peat with roots" and "peat only" in the organic substrate incubation (Fig. 1 and Table 4). The "peat with roots" showed emissions for both gases that were similar to those of the upper peat layer, and emissions from the "peat only" were identical to those of the lower peat layer from the first incubation experiment (see average flux per day in Table 4).
The redox potential (measured at the end of the incubation period) was similar in all three organic substrates (see Table 3). The pH was slightly higher in the "peat with roots". The concentration of soluble reactive phosphorus (SRP) in the pore water was by far highest in the organic sediment. Fe concentrations were highest in the "peat only" and the "peat with roots" and one order of magnitude lower in the organic sediment. Ca concentration was highest in "peat only" compared to the other two substrates.

\section{Discussion}

Despite the fact that the two incubations were performed at different temperatures $\left(20\right.$ vs. $\left.15^{\circ} \mathrm{C}\right)$, incubation periods (363 vs. 53 days), and time since flooding (immediately after versus 2.5 years later) their respective findings can be regarded as complementary and some general conclusions can be drawn regarding the effect of different kinds of substrates on the anaerobic production of GHGs. The upper peat layer (from peat layer incubation) and the "peat with roots" (from the organic substrate incubation) are comparable substrates, since both consist of highly decomposed peat taken from a depth of -0.1 to $-0.2 \mathrm{~m}$ with some remaining plantderived material. Both show similar $\mathrm{CO}_{2}$ and $\mathrm{CH}_{4}$ production rates (Fig. 1 and Table 4).

\subsection{Anaerobic $\mathrm{CO}_{2}$ production - indication of microbial activity}

Anaerobic $\mathrm{CO}_{2}$ production is an indicator for instantaneously available organic substrates from peat and fresh organic matter over a wide range of substances and energetic quality (Freibauer and Augustin, 2009). The organic 
Table 4. Cumulative $\mathrm{CO}_{2}$ and $\mathrm{CH}_{4}$ fluxes over the incubation period (363 days for peat layer incubation; 53 days for organic substrate incubation), average per day (mean $\pm \mathrm{SD}, n=3$ ), total $\mathrm{C}$ in incubation vessels and $\mathrm{C}$ respired during incubation (given as total $\mathrm{C}$ and in $\%$ of total C) (letters indicate differences between the treatments, $p<0.05$ ).

\begin{tabular}{|c|c|c|c|c|c|c|c|c|}
\hline & \multicolumn{2}{|c|}{$\begin{array}{l}\text { Cumulative flux over entire } \\
\text { incubation period }\end{array}$} & \multicolumn{2}{|c|}{ Average flux per day } & \multirow{2}{*}{$\begin{array}{c}\text { Total C at } \\
\text { incubation } \\
\text { start } \\
\text { (g C) }\end{array}$} & \multirow{2}{*}{$\begin{array}{l}\text { Total C } \\
\text { respired during } \\
\text { incubation } \\
\text { (g C) }\end{array}$} & \multicolumn{2}{|c|}{$\begin{array}{l}\% \text { of total C } \\
\text { respired during } \\
\text { incubation }\end{array}$} \\
\hline & $\begin{array}{c}\mathrm{CO}_{2} \text { flux } \\
\left(\mathrm{g} \mathrm{C} \mathrm{kg}^{-1} \mathrm{C}\right)\end{array}$ & $\begin{array}{c}\mathrm{CH}_{4} \text { flux } \\
\left(\mathrm{g} \mathrm{C} \mathrm{kg}^{-1} \mathrm{C}\right)\end{array}$ & $\begin{array}{c}\mathrm{CO}_{2} \text { flux } \\
\left(\mathrm{g} \mathrm{C} \mathrm{d}^{-1} \mathrm{~kg}^{-1} \mathrm{C}\right)\end{array}$ & $\begin{array}{c}\mathrm{CH}_{4} \text { flux } \\
\left(\mathrm{g} \mathrm{Cd}^{-1} \mathrm{~kg}^{-1} \mathrm{C}\right)\end{array}$ & & & $\begin{array}{l}\text { as } \mathrm{CO}_{2} \\
(\%)\end{array}$ & $\begin{array}{l}\text { as } \mathrm{CH}_{4} \\
\quad(\%)\end{array}$ \\
\hline \multicolumn{9}{|c|}{ Peat layer incubation (363 days) } \\
\hline Upper peat layer & $5.5( \pm 0.8)^{\mathrm{a}}$ & $3.4( \pm 0.4)^{\mathrm{a}}$ & $0.02( \pm 0)$ & $0.01( \pm 0)$ & 4500 & $40.2( \pm 5)$ & 0.55 & 0.34 \\
\hline Middle peat layer & $3.2( \pm 0.4)^{\mathrm{b}}$ & $0^{\mathrm{b}}$ & $0.01( \pm 0)$ & 0 & 3500 & $11.1( \pm 1.3)$ & 0.32 & 0 \\
\hline Lower peat layer & $2.4( \pm 1.3)^{\mathrm{b}}$ & $0^{\mathrm{b}}$ & $0.01( \pm 0)$ & 0 & 2500 & $5.9( \pm 3.2)$ & 0.24 & 0 \\
\hline \multicolumn{9}{|c|}{ Organic substrate incubation (53 days) } \\
\hline Organic sediment & $15.2( \pm 1)^{\mathrm{a}}$ & $20.3( \pm 2.3)^{\mathrm{a}}$ & $0.3( \pm 0.02)$ & $0.4( \pm 0.04)$ & $126^{\mathrm{Z}}$ & $4.5( \pm 0.4)$ & 1.52 & 2.03 \\
\hline "Peat with roots" & $1.2( \pm 0.1)^{\mathrm{b}}$ & $0.7( \pm 0.3)^{\mathrm{b}}$ & $0.02( \pm 0)$ & $0.01( \pm 0)$ & $296^{\mathrm{Z}}$ & $0.6( \pm 0.1)$ & 0.12 & 0.07 \\
\hline "Peat only" & $0.4( \pm 0.1)^{\mathrm{b}}$ & $0.03( \pm 0)^{\mathrm{b}}$ & $0.01( \pm 0)$ & 0 & $613^{\mathrm{z}}$ & $0.2( \pm 0.03)$ & 0.04 & 0.003 \\
\hline
\end{tabular}

${ }^{\mathrm{z}}$ Estimated.

sediment consisted mainly of fresh plant litter mixed with sand, and microbial degradation emitting $\mathrm{CO}_{2}$ was, as hypothesized, substantially higher than in the other organic substrates (see Fig. 1c and Table 4). $\mathrm{CO}_{2}$ emissions from the surface of the organic sediment showed a substrate-limited reaction (hyperbolic function with two parameters; $R^{2}=0.87$; Paul and Clark, 1996) from day 9 onwards. The gas accumulated in the substrate matrix, as demonstrated by the gas concentrations in silicone probes (up to $29 \% \mathrm{CO}_{2}$ in the organic sediment, see Fig. 2). In all other substrates with peat from both experiments, specific rates of anaerobic $\mathrm{CO}_{2}$ production were significantly lower. However, significant differences were also recorded between these substrates (Fig. 1). The upper part of the peat profile released significantly more $\mathrm{CO}_{2}$ than peat from deeper down the profile. This could be due to some residual fresh plant-derived material (e.g. from rhizodeposition) which was presumably present in the uppermost peat layer and which could not be removed entirely before incubation. In the situation in which fresh plant roots were present in the peat substrate ("peat with roots"), microbial degradation processes releasing $\mathrm{CO}_{2}$ were more active compared to peat without fresh organic matter ("peat only"). However, the differences were not statistically significant (see Fig. 1c). Anaerobic decomposition depleating "labile" substrates could have occured 2.5 years longer in the peat in the organic substrate incubation. Despite this fact, $\mathrm{CO}_{2}$ production in "peat only" (taken 2.5 years after rewetting) was in the same range than those in the lower peat layer and "peat with roots" was comparable to maximum $\mathrm{CO}_{2}$ emissions from the upper peat layer.

These findings are in accordance with those of another study which reported rates of $\mathrm{CO}_{2}$ and $\mathrm{CH}_{4}$ production that were generally greatest in the surface peat where a strong cover of vegetation had developed and the content of fresh or slightly decomposed plant litter was highest (Glatzel et al., 2004). This suggests that it is the availability of readily degradable plant material that determines $\mathrm{CO}_{2}$ and $\mathrm{CH}_{4}$ production rates, whereupon it only accounts for a small fraction of the total C pool. In our study, only $0.9 \%$ of the initially existing $\mathrm{C}$ from the upper peat layer and $3.5 \%$ from the organic sediment were lost as $\mathrm{CO}_{2}$ or $\mathrm{CH}_{4}$ (see Table 4). Kiikkilä et al. (2011) showed that dissolved organic carbon (DOC) derived from fresh plant material was clearly more degradable and contained a greater amount of labile compounds than DOC derived from the humus layer of a forest soil. Cumulative $\mathrm{CO}_{2}$-loss from forest humus DOC was up to $21 \%$ and was twofold from plant DOC in a 110 days incubation.

Anaerobic $\mathrm{CO}_{2}$ production depends not only on the availability of labile organic substrates but also on the availability of oxidizing substances such as nitrate, ferric iron and sulfate. The concentration of nitrate in the pore water was low throughout the incubation (data not shown). The strong increase in iron concentrations and the depletion of sulfate in the pore water of the upper peat layer indicated that an excess of labile organic substances were available there, in contrast to peat deeper down the profile (Fig. 3). Microbial activity was lower in the middle and lower peat layer as there was a lack of suitable substrate for degradation processes due to the absence of fresh material and the humified nature of the peat. Hence, sulfate concentrations in the pore water decreased only slowly or even increased (see Fig. 3 or Table 3), and favourable conditions for $\mathrm{CH}_{4}$ production were not established throughout incubation. 


\subsection{Onset of methanogenesis and magnitude of $\mathrm{CH}_{4}$ emissions}

The production of $\mathrm{CH}_{4}$ indicates the instantaneous availability of fresh and energy-rich substrates, and it often decreases with depth as does the availability of organic matter (Segers, 1998).

$\mathrm{CH}_{4}$ emissions from the upper peat layer started after a 182-day lag-phase. This retarded onset of methanogenic activity, as well as the zero $\mathrm{CH}_{4}$ emissions from the middle and lower peat layer, can be explained by competition for organic substrates with iron or sulfate reducers. Thus, it took 125 incubation days before sulfate was almost completely gone (see Fig. 3) and methanogenesis started in the upper peat layer (see Fig. 1b). Therefore, we assume that methanogens were inhibited by competition with ironreducing or sulfate-reducing bacteria (Smolders et al., 2002). The slow recovery of methanogenesis during the first weeks under waterlogged conditions in the upper peat layer could also be caused by aerobic conditions in the field before sampling. Aerobiosis could damage a methanogenic population either directly by poisoning or indirectly by C-starvation due to competition for substrates with aerobic microorganisms (Segers, 1998). However, Knorr and Blodau (2009) found that methanogenesis recovered locally quite quickly from aeration. Finally, decomposition of organic matter and subsequent production of GHGs can also be inhibited by the presence of organic electron acceptors such as humic substances (Segers, 1998; Blodau, 2002), which might be the case in the humified middle and lower peat layer (Zak and Gelbrecht, 2007).

The substrates used for the organic substrate incubation were under anaerobic conditions in the field for a longer period (waterlogged conditions for 2.5 years). We assume therefore that methanogens were not inhibited by aerobiosis in this experiment. Conditions favourable for methanogenesis were established quickly in the organic sediment with its large amount of labile, fresh plant material. Here, $\mathrm{CH}_{4}$ emissions started immediately, increased rapidly and were extremely high. From day 10 onwards, $\mathrm{CH}_{4}$ production showed a substrate-limited reaction (hyperbolic function with two parameters; $R^{2}=0.89$; Paul and Clark, 1996).

In accordance with the substantially lower release of GHGs, the microbial degradation of organic matter was significantly lower in the two peat substrates ("peat with roots" and "peat only"). However, differences in decomposition rates could also clearly be seen between these substrates. Microbial activity in the "peat with roots" with its fresh root material was generally higher and methanogenesis started quickly and increased continuously until the end of incubation. The $\mathrm{CH}_{4}$ formed was not emitted continuously through the surface but accumulated in the substrate up to concentrations of $44 \%$, as shown by the silicone probe results (see Fig. 2). This finding indicates that $\mathrm{CH}_{4}$ production in the peat was higher than detected in the surface emissions. The "peat only" - consisting of peat substrate without any fresh organic matter - showed, as anticipated, very low microbial decomposition and methanogenesis stayed very low over the entire incubation period (Figs. 1d and 2).

Our findings confirm the results by Tuittila et al. (2000), who observed extremely low $\mathrm{CH}_{4}$ emissions from highly decomposed bog peat at an abandoned cut-away site and emphasized the importance of fresh plant litter and root exudates as substrates for methanogenesis. A pulse-labeling experiment showed that recently-assimilated carbon was translocated to the roots and available to soil microbial community as root exudates and emitted as $\mathrm{CH}_{4}$ quickly (King and Reeburgh, 2002). The low availability of appropriate organic substrate for methanogens caused the lack of $\mathrm{CH}_{4}$ production from a Dutch cut-over bog remnant; peat with relatively low lignin and phenolic content, and with a low $\mathrm{C}: \mathrm{N}$, $\mathrm{C}: \mathrm{P}$ and $\mathrm{C}: \mathrm{K}$ ratio had a higher potential for $\mathrm{CH}_{4}$ production (Smolders et al., 2002). The highest rates of anaerobic $\mathrm{CH}_{4}$ production occurred in samples close to the soil surface with fresh peat accumulation and a high water table (Glatzel et al., 2004). The largest anaerobic $\mathrm{CO}_{2}$ and $\mathrm{CH}_{4}$ production were found in peat samples close to the soil surface (Reiche et al., 2010). Our findings show that it is not the quality of the bulk peat substrate itself but the presence of fresh organic matter that determines anaerobic GHG production.

Plants no longer growing on a site can be an important control of $\mathrm{CH}_{4}$ production rates - the highest $\mathrm{CH}_{4}$ production occurred at a bog site where sedges had been growing in the recent past and the decomposition of sedge residues in the peat below the surface supported $\mathrm{CH}_{4}$ production (Yavitt et al., 1997). Field measurements on our sampling site revealed extremely high $\mathrm{CH}_{4}$ emissions (up to $205 \mathrm{~g} \mathrm{C} \mathrm{m}^{-2} \mathrm{yr}^{-1}$ ) in the years following rewetting (Chojnicki et al., 2007; Höper et al., 2008). The reed canary grass (Phalaris arundinacea) at the Zarnekow site - due to its high productivity even under flooded conditions - produced, prior to its dying-off during the first year of inundation, a sufficiently large $\mathrm{C}$ pool for $\mathrm{CH}_{4}$ production (accumulation of $\left.650 \mathrm{~g} \mathrm{C} \mathrm{m}^{-2} \mathrm{yr}^{-1}\right)$. The main part thereof was presumably transferred to the organic sediment layer. In addition, the substrate pool is assumed to be continuously refilled with labile organic matter by litter from submerged macrophytes and helophytes from the nearby littoral zone under the prevailing eutrophic and inundated conditions.

\section{Conclusions}

Although laboratory incubations are not considered suitable for assessing the actual relevance of peatlands as a source or sink for $\mathrm{CO}_{2}$ and $\mathrm{CH}_{4}$, they can be used as an indicator for the production potential of $\mathrm{CO}_{2}$ and $\mathrm{CH}_{4}$ in a certain substrate.

Depending on drainage and land use history after rewetting of fens, highly eutrophic shallow lakes can be formed. The bottom of these lakes is typically characterized by highly 
decomposed peat layers at the top and less decomposed peat layers up to several metres below. The original grassland vegetation is not adapted to inundated conditions and therefore dies back, forming an organic sediment layer. This fresh organic substrate has an extremely high potential for $\mathrm{CH}_{4}$ production. Consequently, the release of $\mathrm{CH}_{4}$ could be high at least as long as eutrophic and inundated conditions last.

In contrast, pure peat without fresh plant-derived material seems to be relatively inert. Significant methane emissions cannot be expected from pure peat layers under permanently inundated conditions in the field as long as readily degradable substances are lacking.

To some extent, GHG production may occur when some labile organic matter is available, e.g from rhizodeposition or fresh litter from plant roots. However, depending on the availability of alternative electron acceptors (e.g. iron and sulfate), $\mathrm{CH}_{4}$ production will start after an extended lagphase, and the available $\mathrm{C}$ pool is more limited than in the newly formed sediment layer.

The risk of high $\mathrm{CO}_{2}$ and $\mathrm{CH}_{4}$ emissions after restoration is limited to waterlogged conditions and the simultaneous presence of readily degradable and energy-rich substrates for microbial decomposition processes (i.e. eutrophic peat, fresh plant litter, or newly formed organic sediments, e.g. from plants that are not adapted to flooding). In the future, it should be investigated if the expected colonization of flooded areas by adapted plant species such as Typha sp., reeds or sedges might also reduce this potential risk as their litter is slowly decomposed (Brinson et al., 1981).

Acknowledgements. We are grateful to Susan Trumbore from the Max Planck Institute for Biogeochemistry for critically revising the draft. We wish to thank Bodo Grossmann (Leibniz Centre for Agricultural Landscape Research) for his excellent technical assistance in gas analysis. Funding for this research was provided by the Federal Ministry of Education and Research (BMBF) through the integrative project "Climate mitigation via peatland management" (FKZ 01LS05051) and by the Landesamt für Umwelt, Naturschutz und Geologie Mecklenburg-Vorpommern ("Emission klimarelevanter Spurengase aus wiedervernässten Mooren im Peenetal”, LUNG 230-5325.60-7-35).

The service charges for this open access publication have been covered by the Max Planck Society.

Edited by: A. Neftel

\section{References}

Alm, J., Shurpali, N. J., Minkkinen, K., Aro, L., Hytönen, J., Laurila, T., Lohila, A., Maljanen, M., Martikainen, P. J., Mäkiranta, P., Penttilä, T., Saarnio, S., Silvan, N., Tuittila, E. S., and Laine, J.: Emission factors and their uncertainty for the exchange of $\mathrm{CO}_{2}, \mathrm{CH}_{4}$ and $\mathrm{N}_{2} \mathrm{O}$ in Finnish managed peatlands, Boreal Environ. Res., 12, 191-209, 2007.
Augustin, J.: Emission, Aufnahme und Klimarelevanz von Spurengasen, in: Landschaftsökologische Moorkunde, 2 Edn., edited by: Joosten, H. and Succow, M., Schweizerbart'sche Verlagsbuchhandlung, Stuttgart, 28-37, 2001.

Blodau, C.: Carbon cycling in peatlands - a review of processes and controls, Environ. Rev., 10, 111-134, doi:10.1139/A02-004, 2002.

Brinson, M. M., Lugo, A. E., and Brown, S.: Primary productivity, decomposition, and consumer activity in freshwater wetlands., Annu. Rev. Ecol. Syst., 12, 123-161, 1981.

Chojnicki, B. H., Augustin, J., and Olejnik, J.: Impact of reflooding on greenhouse gas exchange of degraded fen peatlands, in: Proceedings of the $1^{\text {st }}$ International Symposium on Carbon in Peatlands, Wageningen, The Netherlands, 15-18 April 2007, 2007.

Clymo, R. S.: The limits to peat bog growth, Philos. T. Roy. Soc. B, 303, 605-654, 1984.

Conrad, R.: Control of methane production in terrestrial ecosystems, in: Exchange of Trace Gases Between Terrestrial Ecosystems and the Atmosphere, edited by: Andrea, M. O. and Schimel, D. S., Wiley, New York, 39-58, 1989.

Drösler, M.: Trace gas exchange and climatic relevance of bog ecosystems, Southern Germany, PhD thesis, Chair of Vegetation Ecology, Department of Ecology, Technical University Munich, 179 pp., 2005.

Drösler, M., Freibauer, A., Christensen, T. R., and Friborg, T.: Observations and status of peatland greenhouse gas emissions in Europe, in: The Continental-Scale Greenhouse Gas Balance of Europe, edited by: Dolman, V. A. F., Springer, New York, p. 387, 2008.

Freibauer, A. and Augustin, J.: Interactive comment on "Effect of peat quality on microbial greenhouse gas formation in an acidic fen" by M. Reiche et al., Biogeosciences Discussions, 6, C2593C2601, available at: http://www.biogeosciences-discuss.net/6/ C2593/2009/, 2009.

Glatzel, S., Basiliko, N., and Moore, T.: Carbon dioxide and methane production potentials of peat from natural, harvested and restored sites, Wetlands, 24, 261-267, 2004.

Gorham, E.: Northern peatlands: role in the carbon cycle and probable responses to climatic warming, Ecol. Appl., 1, 182-195, 1991.

Hendriks, D. M. D., van Huissteden, J., Dolman, A. J., and van der Molen, M. K.: The full greenhouse gas balance of an abandoned peat meadow, Biogeosciences, 4, 411-424, doi:10.5194/bg-4411-2007, 2007.

Houghton, J. T., Jenkins, G. J., and Ephraums, J. J.: Climate Change, The IPCC Scientific Assessment, Cambridge University Press, Cambridge, 410 pp., www.ipcc.ch/publications_and_data/ publications_ipcc_first_assessment_1990_wg1.shtml, 1990.

Höper, H., Augustin, J., Cagampan, J. P., Drösler, M., Lundin, L., Moors, E., Vasander, H., Waddington, J. M., and Wilson, D.: Restoration of peatlands and greenhouse gas balances, in: Peatlands and Climate Change, edited by: Strack, M., International Peat Society, Jyväskylä, 182-210, 2008.

Joosten, H. and Succow, M.: Hydrogenetische Moortypen, in: Landschaftsökologische Moorkunde, 2 Edn., edited by: Joosten, H. and Succow, M., Schweizerbart'sche Verlagsbuchhandlung, Stuttgart, 234-240, 2001.

Juutinen, S., Larmola, T., Remus, R., Mirus, E., Merbach, W., Silvola, J., and Augustin, J.: The contribution of Phrag- 
mites australis litter to methane $\left(\mathrm{CH}_{4}\right)$ emission in planted and non-planted fen microcosms, Biol. Fert. Soils, 38, 10-14, doi:10.1007/s00374-003-0618-1, 2003.

Kammann, C., Grünhage, L., and Jäger, H. J.: A new sampling technique to monitor concentrations of $\mathrm{CH}_{4}, \mathrm{~N}_{2} \mathrm{O}$ and $\mathrm{CO}_{2}$ in air at well-defined depths in soils with varied water potential, Eur. J. Soil Sci., 52, 297-303, 2001.

Kiikkilä, O., Kitunen, V., and Smolander, A.: Properties of dissolved organic matter derived from silver birch and Norway spruce stands: Degradability combined with chemical characteristics. Soil Biol. Biochem., 43, 421-430, 2011.

King, J. Y. and Reeburgh, W. S.: A pulse-labeling experiment to determine the contribution of recent plant photosynthates to net methane emission in arctic wet sedge tundra, Soil Biol. Biochem., 34, 173-180, 2002.

Knorr, K. H. and Blodau, C.: Impact of experimental drought and rewetting on redox transformations and methanogenesis in mesocosms of a northern fen soil, Soil Biol. Biochem., 41, 11871198, doi:10.1016/j.soilbio.2009.02.030, 2009.

Lenschow, U., Jeschke, L., Zscheile, K. H., and Ziese, B.: Geologie und Landschaftsgeschichte Mecklenburg-Vorpommerns, in: Die Naturschutzgebiete in Mecklenburg-Vorpommern, Demmler Verlag GmbH, Schwerin, p. 713, 2003.

Loftfield, N., Flessa, H., Augustin, J., and Beese, F.: Automated gas chromatographic system for rapid analysis of the atmospheric trace gases methane, carbon dioxide, and nitrous oxide, J. Environ. Qual., 26, 560-564, 1997.

Nykänen, H., Alm, J., Silvola, J., Tolonen, K., and Martikainen, P. J.: Methane fluxes on boreal peatlands of different fertility and the effect of long-term experimental lowering of the water table on flux rates, Global Biogeochem. Cy., 12, 53-69, 1998.

Okruszko, H.: Influence of hydrological differentiation of fens on their transformation after dehydration and on possibilities for restoration, in: Restoration of Temperate Wetlands, edited by: Wheeler, B. D., Shaw, S. C., Fojt, W. J., and Robertson, R. A., Wiley, Chichester, UK, 113-119, 1995.

Paul, E. A. and Clark, F. E.: Soil organic matter turnover: pool sizes and reaction kinetics, in: Soil Microbiology and Biochemistry, 2 Edn., edited by: Paul, E. A. and Clark, F. E., Academic Press, San Diego, CA, USA, 1996.

Puustjärvi, V.: Degree of humification, Peat Plant News, 3, 48-52, 1970.

R: A Language and Environment for Statistical Computing, R Development Core Team, R Foundation for Statistical Computing, Vienna, Austria, 2009.
Reiche, M., Gleixner, G., and Küsel, K.: Effect of peat quality on microbial greenhouse gas formation in an acidic fen, Biogeosciences, 7, 187-198, doi:10.5194/bg-7-187-2010, 2010.

Schinner, F.: Bodenatmung, in: Bodenbiologische Arbeitsmethoden, edited by: Schinner, F., Öhlinger, R., Kandeler, E., and Margesin, R., Springer, Berlin, Heidelberg, 84-86, 1993.

Segers, R.: Methane production and methane consumption: a review of processes underlying wetland methane fluxes, Biogeochemistry, 41, 23-51, 1998.

Smolders, A. J. P., Tomassen, H. B. M., Lamers, L. P. M., Lomans, B. P., and Roelofs, J. G. M.: Peat bog restoration by floating raft formation: the effects of groundwater and peat quality, $\mathrm{J}$. Appl. Ecol., 39, 391-401, 2002.

Tuittila, E. S., Komulainen, V. M., Vasander, H., Nykänen, H., Martikainen, P. J., and Laine, J.: Methane dynamics of a restored cut-away peatland, Glob. Change Biol., 6, 569-581, 2000.

Umweltbundesamt: Nationaler Inventarbericht zum Deutschen Treibhausgasinventar 1990-2007, Umweltbundesamt, Dessau, 575 pp., 2009.

Wilson, D., Alm, J., Laine, J., Byrne, K. A., Farell, E. P., and Tuittila, E. S.: Rewetting of cutaway peatlands: are we re-creating hot spots of methane emissions?, J. Soc. Ecol. Restor. Int., 17, 796-806, doi:10.1111/j.1526-100X.2008.00416.x, 2008.

Yavitt, J. B., Williams, C. J., and Wieder, R. K.: Production of methane and carbon dioxide in peatland ecosystems across North America: effects of temperature, aeration, and organic chemistry of peat, Geomicrobiol. J., 14, 299-316, 1997.

Zak, D. and Gelbrecht, J.: The mobilisation of phosphorus, organic carbon and ammonium in the initial stage of fen rewetting (a case study from NE Germany), Biogeochemistry, 85, 141151, doi:10.1007/s10533-007-9122-2, 2007.

Zak, D., Gelbrecht, J., Wagner, C., and Steinberg, C. E. W.: Evaluation of phosphorus mobilisation potential in rewetted fens by an improved sequential chemical extraction procedure, Eur. J. Soil Sci., 59, 1191-1201, doi:10.1111/j.1365-2389.2008.01081.x, 2008.

Zak, D., Wagner, C., Payer, B., Augustin, J., and Gelbrecht, J.: Phosphorus mobilization in rewetted fens: the effect of altered peat properties and implications for their restoration, Ecol. Appl., 20, 1336-1349, doi:10.1890/08-2053, 2010. 